
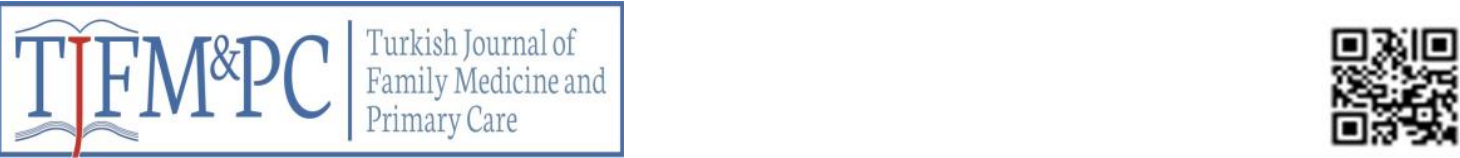

Original Research / Özgün Araştırma

\title{
Awareness of Pregnants About the Harms of Smoking to Baby- Multi-centered Primary Care Research
}

\section{Gebelerin Sigaranın Bebeğe Zararları Hakkındaki Farkındalıkları - Çok Merkezli Birinci Basamak Araştırması}

Onur Öztürk ${ }^{* 1}$, Mustafa Ünal ${ }^{2}$, Gülşah Öztürk ${ }^{3}$ İzzet Fidancl ${ }^{4}$, Özlem Klzlltaş5

\begin{abstract}
Objective: Smoking habits of the pregnant woman do not only affect her, but also raise the health risks of the baby. Smoking is a preventable risk factor for pregnancy-related mortality and morbidity. In this study, pregnant women's awareness about the level of health problems that can be caused by smoking on the infants are questioned. Methods: This study was a descriptive, cross-sectional type field study and 4 family health centers from different regions were participated. The questionnaire was formed based on literature to elaborate women knowledge about risks to babies and included 13 questions (6 were personal and 7 were on smoking). Results: The mean age of participants $(n=124)$ was $27,4 \pm 5,8$. Majority of current pregnancies were voluntary $(84,7 \%)$. Although only $2,4 \%$ of the pregnants smoked, $48.4 \%$ of them exposed to smoke by the spouse or someone close. When asked how many cigarettes daily could harm a baby, $87.1 \%$ of them thought that even 1 a day would suffice. The highest awareness rate among the problems was death / preterm delivery (59\%). As the education level increased, the level of knowledge is increased, but the rate of smoking did not change. The level of knowledge was much higher in voluntary pregnancies. Conclusion: We found that our pregnant women had a very low level of cigarette smoking but did not have enough information about the negative effects of cigarette on the baby. Health personnel working in family health centers should educate the pregnant women about the consequences of active or passive exposure to cigarette smoke.
\end{abstract}

Key words: Pregnant, smoking, harm, awareness, baby

ÖZET

Amaç: Gebenin, sigara alışkanlığı yalnızca kendisini etkilemekle kalmaz, doğacak bebeğin de sağlığını riske sokar. Gebelikte sigara içimi, gebelik ile ilişkili mortalite ve morbidite için önlenebilir bir risk faktörüdür. Bu çalışmada, gebelerin sigaranın bebeklerde yol açabileceği sağlık problemlerini, ne düzeyde bildiği sorgulanmıștır. Yöntem: Bu çalıșma, tanımlayıcı, kesitsel tipte saha çalıșması olup, farklı il ve ilçelerden toplam dört aile sağlı̆̆ı merkezi dahil edilmiştir. Literatür derlemesi ile oluşturulan, 6'sı kişisel veriyi, 7'si de sigara içimini sorgulayan, toplam 13 soruluk bir anketle gebeler sorgulanmış, sigaranın bebeklerde yol açabileceği sağlık problemlerini ne düzeyde bildikleri ölçülmüştür. Bulgular: Çalışmaya dahil edilen katılımcıların ( $\mathrm{n}=124)$ yaş ortalaması 27,4 $\pm 5,8$ idi. Mevcut gebeliklerin \%84,7'i istemli oluşmuştur. Gebelerin, \%2,4'ü sigara içiyordu ve \%48,4'ünün eşi veya yakınındakilerin kendilerinin yanında sigara içtiği görüldü. Günlük kaç sigaranın bebeğe zarar verebileceği sorulduğunda, \%87,1'inin günde 1 tane içmelerinin bile yeterli olacağını düşündüğ̈ gözlendi. Sigaranın yol açacağı problemlerden bilinirlik oranı en yüksek olanı, ölü/ erken doğum idi (\%59). Eğitim düzeyi arttıkça, gelişebilecek problemler konusunda bilgili olma düzeyi artmaktaydı, fakat sigara içicisi olma oranı değişmemekteydi. İsteyerek gebe kalanlarda bilgili olma düzeyi çok daha yüksekti. Sonuç: Gebelerimizin sigara içiciliğinin çok düşük düzeyde olduğu, fakat sigaranın bebek üzerindeki olumsuz etkileri konusunda yeterli bilgi düzeyine sahip olmadıkları görüldü. Özellikle aile sağlı̆̆ı merkezlerinde görev yapan sağlık personelinin, gebeleri aktif ya da pasif sigara maruziyetinin sonuçları konusunda bilgilendirmeleri gerekmektedir.

Anahtar kelimeler: Gebe, sigara, zarar, farkındalık, bebek

Received Date / Geliş Tarihi: 04.02.2018 Accepted Date / Kabul Tarihi: 24.04.2018

${ }^{1}$ Asarcık Meydan Aile Sağllğ 1 Merkezi, SAMSUN

${ }^{2}$ Ondokuz Mayıs Üniversitesi Tıp Fakültesi Aile Hekimliği Anabilim Dalı, SAMSUN

${ }^{3}$ Asarcık Devlet Hastanesi, Aile Hekimliği Kliniği, SAMSUN

${ }^{4}$ Mamak Kıbrıs Aile Sağ 1 ğı Merkezi, ANKARA

${ }^{5}$ Haliliye Bağlarbaşı Aile Sağlığı Merkezi, ŞANLIURFA

*Address for Correspondence / Yazışma Adresi: Onur Öztürk, Asarcık Meydan Aile Sağlığı Merkezi, SAMSUN

E-mail:dr.onurozturk@yahoo.com

Öztürk O, Ünal M, Öztürk G, Fidancı İ, Kızıltaş Ö. Gebelerin Sigaranın Bebeğe Zararları Hakkındaki Farkındalıkları -Çok

Merkezli Birinci Basamak Araştırması. TJFMPC, 2018;12 (4):233-238. DOI: 10.21763/tjfmpc.462912 


\section{GíRiș}

Gebelik, fizyolojik ve önemli bir deneyimdir. Gebenin sigara alışkanlığı, yalnızca kendisini etkilemekle kalmaz, doğacak bebeğin de sağlığını riske sokar. ${ }^{1}$ Günümüzde, önlenebilir hastalıkların ana nedeni sigara olmasına karşın, bu bilgi halen yeteri kadar bilinmemekte ve önemsenmemektedir. Öyle ki, her yil beş milyondan fazla kişinin ölümüne neden olan bu alışkanlıktan ötürü 2030 yılında sekiz milyon insanın öleceği ön görülmektedir. Küresel Yetişkin Tütün Araştırması 2012 sonuçlarına göre, Türkiye'de sigara içme sıklığı erkeklerde \%41,4, kadınlarda \%13,1 olarak tespit edilmiştir. ${ }^{2}$

Kadın popülasyonda sigara tüketiminin yüksek olması, sigaradan kaynaklanan gebelik ile ilgili risklerin de artmasına neden olmaktadır. ${ }^{3}$ Amerika Birleşik Devletleri'nde, kadınların en azından $\% 11$ 'i gebeliklerinde sigara içmektedirler ${ }^{4}$ ve bütün gebe kadınların sigarayı bırakması durumunda, ölü doğumlarda \%11 ve yeni doğan ölümlerinde $\% 5$ azalma olacağ 1 tahmin edilmektedir. ${ }^{5}$ Sigara içiminin, anne ve bebek sağlığı üzerine etkilerine dair birçok çalışma yapılmıştır. Gebelikte sigara içimi, gebelik ile ilişkili mortalite ve morbidite için önlenebilir bir risk faktörüdür. Sigaraya maruz kalan bebeğin gelişimi, uterus ile plasenta arasındaki damarların daralması ve tıkanması sonucunda bozulmaktadır. ${ }^{6}$ Ayrıca, nikotinin ve karbon monoksitin farklı mekanizmalarla gebelik süreçlerini olumsuz etkilediği bilinmektedir. ${ }^{7,8} \mathrm{Bu}$ çalışmada, gebelerin sigaranın bebeklerde yol açabileceği sağlık problemlerini ne düzeyde bildiği sorgulanmıştır.

\section{YÖNTEM}

$\mathrm{Bu}$ çalışma, tanımlayıcı, kesitsel tipte saha çalışması olup Kasım-Aralık 2017 tarihleri arasında yapılmıştır. Ankara/Mamak ilçesi, Ordu/Ünye ilçesi, Samsun/Asarcık ilçesi ve Şanlıurfa/Haliliye ilçesinden birer tane olmak üzere, toplam 4 aile sağlığı merkezi (ASM) dahil edilmiştir. Araştırmanın evrenini, ilgili aile hekimliği birimlerinin nüfuslarına kayıtlı 218 adet gebe oluşturmaktadır. Gebelerin hepsine ulaşılıp, ilgili anketler ve çalışmanın maksadı anlatıldıktan sonra, gönüllü olan 159 gebeden, anketleri eksiksiz dolduran 124'ü çalışmaya alınmıştır. Literatür derlemesi ile oluşturulan, 6'sı kişisel veriyi, 7'si de sigara içimini sorgulayan, toplam 13 soruluk bir anketle gebeler sorgulanmış, sigaranın bebeklerde yol açabileceği sağlık problemlerini ne düzeyde bildikleri ölçülmüştür. Aylık toplam geliri sorgulayan demografik soruda, Türkiye için o dönemin şartlarında belirlenen açlık sınırı yaklaşık $1500 \mathrm{TL}$, yoksulluk sınırı ise yaklaşık $5000 \mathrm{TL}$ olarak baz alınmıştır.
Çalışmadan elde edilen verilerin özetlenmesinde, tanımlayıcı istatistikler, sürekli değişkenler için ortalama \pm standart sapma olarak tablo halinde verilmiştir. Kategorik değişkenler, sayı ve yüzde olarak özetlenmiştir. Kategorik değişkenler arasındaki farklılık karşılaştırmalarında, Fisher Freeman Halton Testi kullanılmıştır. İstatistiksel analizler, R 3.3.2v (açık kaynak) programı ile yapılmış ve istatistik analizlerde anlamlılık düzeyi 0.05 (p-value) olarak dikkate alınmıştır. Etik kurul onay1, Samsun 19 Mayıs Üniversitesi Klinik Araştırmalar Etik Kurulunca Kasım 2017'de çıkartılmıştır.

\section{BULGULAR}

Çalışmaya dahil edilen katılımcıların $(n=124)$ yaş ortalaması 27,4 $\pm 5,8$ idi. Kadınların gebelik haftalarına bakıldığında, \%21'inin birinci, $\% 43,5$ 'inin ikinci ve $\% 35,5$ 'inin üçüncü trimester döneminde olduğu görüldü. Mevcut gebeliklerin $\% 84,7$ 'si istemli, \%15,3'ü ise istemsiz oluşmuştur. Gebelerin, \%32,3'sının ilk gebeliği, \%28,2'sinin ikinci gebeliği idi. Ortaöğretim mezunu olanlar $(\% 42,7)$ ağırlıkta idi. Yaşadıkları evin toplam gelirine bakıldığında, \%44,5'inin açlık sınırı, \%46'sinin yoksulluk sınırında olduğu görüldü. Tablo 1'de, çalışmaya dahil edilen gebelerin demografik özelliklerine ait bilgiler verilmiştir.

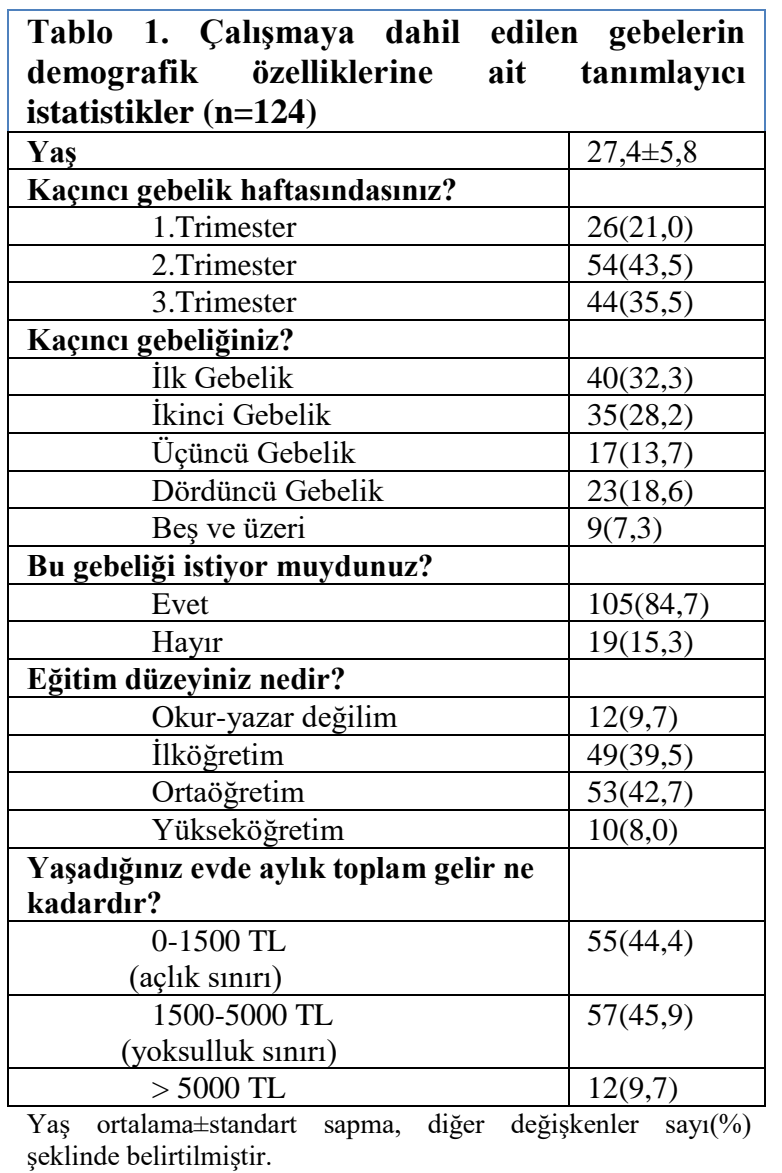


Gebelerin \%2,4’ü sigara içiyorken, \%12,9'unun gebelikte bıraktığı, \%84,7'sinin ise sigara kullanmadığı saptand1. Katılımcıların, \%48,4'unun eşlerinin veya yakınındakilerin kendilerinin yanında sigara içtiği görüldü. Günlük kaç sigaranın bebeğe zarar verebileceği sorulduğunda, \%87,1'inin günde 1 tane içmelerinin bile yeterli olacağını düşündüğü gözlendi. Sigaranın, bebeklerine verebileceği zararların, gebeleri ne kadar endişelendirdiği araştırıldığında, \%64,5'inin çok fazla endişelendiği, $\% 2,4$ 'ünün ise endişelenmediği sonucuna varıldı. Sigara içen bir gebenin, bebeğine vereceği zararın gebenin kendisine kiyasla ne kadar olduğu araştırıldığında ise, \%75,8'inin anneden daha fazla zarar verdiğini düşündüğü görüldü. Gebelerin yanında içilen sigaranın, bebeklerine vereceği zararın, gebeye kıyasla ne kadar olacağına bakıldığında ise, \%74,2'sinin anneden daha fazla zarar verdiği düşüncesinde olduğu görüldü. Gebelerin sigara içmesi veya yanlarında sigara içilmesinin bebek açısından hangi sorun veya sorunlara yol açacağı araştırıldığında, \%53,2'sinin düşük doğum ağırlık lığına, \%59,7'sinin ölü veya erken doğuma, \%11,3'unun doğumsal vücut anomalilerine, \%37,1'inin akciğer fonksiyonlarında eksikliklere, \%20,2'sının beyin fonksiyonlarında eksikliklere, \%17'sinin düşük tehdidine, \%3,2'sinin hipertansiyona ve $\% 9,7$ 'sinin çocukluk kanserlerine yol açabileceğini belirttikleri görüldü. Çalışmaya dâhil edilen kadınların, sigara içme, maruz kalma ve bilgi seviyesi ile ilgili oranlar Tablo 2'de verilmiştir.

Gebelerin, kaçıncı trimesterde olduğu ile sigara içme durumları arasında ilişki görülmedi. "Sigara içen gebenin, bebeğine vereceği zarar, gebenin kendisine kıyasla ne kadardır?" sorusunda, anneden daha fazla zarar vereceğini düşünen 1.trimester dönemindeki kadınların oranı, 2.trimester döneminde olan kadınlara göre anlamlı düzeyde daha yüksek $(p=0,007) \quad$ çıktığı sonucuna varıldı.Gebelerin, kaçıncı gebeliğinde olduğunun sigara içip içmeme, bebeği için endişelenme, sigaranın bebek üzerindeki zararının, anneye zararıyla kıyaslanması arasındaki farklılık istatistiksel olarak anlamlı bulunmadı.

"Sigara içen gebenin, bebeğine vereceği zarar, gebenin kendisine kıyasla ne kadardır?" sorusuna anneden daha fazla zarar vereceğini düşünen, isteyerek gebe kalan kadınların oranının $(\% 79,1)$, istemeden gebe kalanlara göre $(\% 57,9)$ daha fazla $(\mathrm{p}=0,03)$ olduğu görüldü. Gebelerin, sigara içip içmemesi ile eşlerinin veya yakınındakilerin sigara içip içmemesi arasında, anlamlı bir ilişki tespit edilemedi. Keza, gebelerin sigara içip içmemesi ile "günlük kaç sigaranın bebeğe zararlı olabileceği" sorusuna verilen cevaplar ve bebeğin göreceği zararlara karşı endişe duyma seviyesi arasında da anlamlı bir ilişki tespit edilemedi.

\begin{tabular}{|c|c|}
\hline $\begin{array}{l}\text { Tablo 2. Gebelerin sigara } \\
\text { durumlarına ait tanımlayıcı } \\
(\mathrm{n}=124)\end{array}$ & $\begin{array}{l}\text { ile ilgili } \\
\text { statistikler }\end{array}$ \\
\hline \multicolumn{2}{|l|}{ Sigara içiyor musunuz? } \\
\hline Evet & $3(2,42)$ \\
\hline Gebelikte bıraktım & $16(12,9)$ \\
\hline Hayır & $105(84,7)$ \\
\hline \multicolumn{2}{|l|}{$\begin{array}{l}\text { Eşiniz veya yakınınızdakiler sizin } \\
\text { yanınızda sigara içiyor mu? }\end{array}$} \\
\hline Evet & $60(48,4)$ \\
\hline Hayır & $64(51,6)$ \\
\hline \multicolumn{2}{|l|}{$\begin{array}{l}\text { Sizce günlük kaç sigara bebeğe zararlı } \\
\text { olabilir? }\end{array}$} \\
\hline Günde 1 tane bile yeterli & $108(87,1)$ \\
\hline Günde 5-10 adet & $10(8,1)$ \\
\hline Günde 11 ve üzeri & $6(4,8)$ \\
\hline \multicolumn{2}{|l|}{$\begin{array}{l}\text { Sigaranın bebeğinize verebileceği } \\
\text { zararlar sizi ne kadar endișelendiriyor? }\end{array}$} \\
\hline Çok fazla & $80(64,5)$ \\
\hline Fazla & $22(17,7)$ \\
\hline Bir fikrim yok & $13(10,5)$ \\
\hline Biraz & $6(4,8)$ \\
\hline Endișelenmiyorum & $3(2,4)$ \\
\hline \multicolumn{2}{|l|}{$\begin{array}{l}\text { Sigara içen gebenin, bebeğine vereceği } \\
\text { zarar, gebenin kendisine klyasla ne } \\
\text { kadardır? }\end{array}$} \\
\hline Anneden daha fazla zarar verir & $94(75,8)$ \\
\hline Anne kadar zarar verir & $24(19,4)$ \\
\hline Anneden daha az zarar verir & $5(4,0)$ \\
\hline Zarar vermez & $1(0,8)$ \\
\hline \multicolumn{2}{|l|}{$\begin{array}{l}\text { Yanınızda içilen sigaranın bebeğinize } \\
\text { vereceği zarar, size kıyasla ne kadardır? }\end{array}$} \\
\hline Anneden daha fazla zarar verir & $92(74,2)$ \\
\hline Anne kadar zarar verir & $24(19,4)$ \\
\hline Anneden daha az zarar verir & $7(5,7)$ \\
\hline Zarar vermez & $1(0,8)$ \\
\hline \multicolumn{2}{|l|}{$\begin{array}{l}\text { Sigara içmeniz veya yanınızda sigara } \\
\text { içilmesi, } \\
\text { bebek açısından hangi soruna veya } \\
\text { sorunlara yol açabilir? }\end{array}$} \\
\hline \multicolumn{2}{|l|}{ Düşük doğum ağırlıklı olma } \\
\hline Hayır & $58(46,8)$ \\
\hline Evet & $66(53,2)$ \\
\hline \multicolumn{2}{|l|}{ Ölü veya erken doğum } \\
\hline Hayır & $50(40,3)$ \\
\hline Evet & $74(59,7)$ \\
\hline \multicolumn{2}{|l|}{ Doğumsal vücut anomalileri } \\
\hline Hayır & $110(88,7)$ \\
\hline Evet & $14(11,3)$ \\
\hline \multicolumn{2}{|l|}{ Akciğer fonksiyonlarında eksiklikler } \\
\hline Hayır & $78(62,9)$ \\
\hline Evet & $46(37,1)$ \\
\hline \multicolumn{2}{|l|}{ Beyin fonksiyonlarında eksiklikler } \\
\hline Hayır & $99(79,8)$ \\
\hline Evet & $25(20,2)$ \\
\hline \multicolumn{2}{|l|}{ Düşük tehditi } \\
\hline Hayır & $103(83,1)$ \\
\hline Evet & $21(16,9)$ \\
\hline \multicolumn{2}{|l|}{ Hipertansiyon } \\
\hline Hayır & $120(96,8)$ \\
\hline Evet & $4(3,2)$ \\
\hline \multicolumn{2}{|l|}{ Çocukluk kanserleri } \\
\hline Hayır & $112(90,3)$ \\
\hline Evet & $12(9,7)$ \\
\hline \multicolumn{2}{|l|}{ Hiçbiri } \\
\hline Hayır & $118(95,2)$ \\
\hline Evet & $6(4,8)$ \\
\hline
\end{tabular}

Değişkenler sayı(\%) şeklinde belirtilmiştir.

Maddi durumu iyi olan gebelerin, iyi olmayanlara göre daha çok $(p=0,009)$ sigara içtiği söylenebilir. 
Ayrıca, aylık gelirleri yoksulluk sınırında olan gebelerin eşleri veya yakınındakilerin, yanlarında sigara içme oranı maddi durumu iyi olanlara göre, anlamlı düzeyde daha yüksek $(p=0,042)$ olduğu tespit edilmiştir. Gelir düzeyi açlık sınırında olan gebelerden, sigara içmelerinin veya yanlarında sigara içilmesinin, bebeğin beyin fonksiyonlarında probleme yol açabileceğini düşünenlerin oranı, yoksulluk sınırında olanlara göre anlamlı düzeyde daha yüksek $(\mathrm{p}=0,026)$ çıkmıştır.

İsteyerek gebe kalan kadınlar arasında, sigara kaynaklı düşük doğum ağırlıklı olma ve ölü/erken doğum gibi sorunların olabileceğini düşünenlerin oranı, istemeden gebe kalanlara göre anlamlı düzeyde daha yüksekti (sırayla $\mathrm{p}=0,04, \mathrm{p}=0,027$ ).

Eğitim durumuna göre, sigara içicisi olma durumu değişmezken, eğitim düzeyi arttıkça, kadınların sigara içmelerinin veya yanlarında sigara içilmesinin, bebek açısından düşük doğum ağırlıklı olma sorununa yol açabileceğini düşünenlerin oranı $\operatorname{artmıştır~}(\mathrm{p}=0,037)$.

Bulgularımıza göre, eşleri veya yakınındakileri sigara içmeyen gebeler, sigaranın bebeğe verebileceği zararlar konusunda daha endişelidir $(p<0,001)$. Sigaranın, bebeğe verebileceği zarar konusunda endişelenme seviyesi arttıkça aktif veya pasif sigara tüketiminin bebeğe anneden daha fazla $(p<0,001)$ zarar vereceği düşünülmekteydi. Yine, endişelenme seviyesi arttıkça, bebeğin karşılaşabileceği sorunlardan düşük doğum ağırlığı ve ölü/erken doğum riski daha çok biliniyordu (sirayla $\mathrm{p}=0,005, \mathrm{p}=0,013$ ).

Günde bir sigaranın bile, bebeğe zararlı olabileceğini düşünen gebeler, sigaranın bebeğe verebileceği zararlar konusunda daha endişelidir $(\mathrm{p}=0,003)$. Günde, ancak 11 ve üzeri sigaranın bebeğe zararlı olabileceğini düşünen gebeler, aktif veya pasif sigara tüketiminin bebeğe anneden daha az zarar vereceğini düşünmekteydiler (sırayla $p=0,001, p=0,003)$. Günde, kaç sigaranın bebeğe zarar verebileceği sorusu ile, sigara içilmesinin bebeğe yol açabileceği sorunlara ait oranlar karşılaştırıldığında, anlamlı farklılık bulunmamıştır. Aktif ve pasif içiciliğinin, bebekte anneden daha fazla sorun yaratacağını düşünenlerde, bebeğin karşılaşabileceği sorunlardan ölü/erken doğum riski daha çok biliniyordu (sırayla $\mathrm{p}=0,001, \mathrm{p}=0,005$ ).

Yakınları yanlarında sigara içen kadınlarda, yanında sigara içilmeyenlere göre, bebekte düşük doğum ağırlıklı olma ve ölü veya erken doğum riskinin bilinme oranı daha düşüktü (sırayla $\mathrm{p}=0,012, \mathrm{p}=0,013)$.

\section{TARTIŞMA}

Gebelerde sigara içiciliği oranı \%6,8-\%28 arasında değişen ülkemizde, ortalama değer \%12 civarındadır. ${ }^{9-11}$ Ananth ve ark., 61667 gebe kadını içeren prospektif çalışmalarında, sigara içme oranın $1 \% 33$ olarak bulmuştur. ${ }^{12}$ Gomez ve ark. İse, Fransa'da gebe popülasyonundaki sigara içim oranını \%25,1 olarak bulmuştur. ${ }^{13}$ Bizim çalışmamızda bu oran \%2,4 olarak bulunmuştur ve en düşük oranlı çalışmalardan biridir. Okuma, yazma, anlama yetersizliğinden soruları tam anlayamayan veya eksik dolduran gebeler de çalışmaya dahil edilse idi, sigara içme oranı azalabilir veya artabilirdi.

Ülkemizde yapılan bir çalışmaya göre, gebelerin \%21,3’ü gebelik öncesinde sigara kullanmakta iken, \%12,8'i gebelik sirasında sigara kullanmıştır. ${ }^{1}$ Başka bir çalışmada ise, anne adaylarının \%34,7'sinin gebelikten önce sigara içtiği, \%14'ünün gebeliği sırasında sigara içtiği görülmüştür. ${ }^{14} \mathrm{Bu}$ da, gebelik psikolojisinin başlı başına sigarayı bırakma/azaltma metodu olduğunu göstermektedir. Öyle ki, kendi gebelerimizin de \%12,9'u sigarayı gebeliklerinde bırakmıştı.

Altıparmak'ın çalışmasında, gebelerin yaş ortalaması 26,7 idi ve katılımcılar ağırlıklı olarak ilkokul mezunuydu. ${ }^{1}$ Marakoğlu ve Erdem'in çalışmasında ise, yaş ortalaması 28,4 bulunmuştur. ${ }^{15}$ Mutlu'nun çalışmasında, yaş ortalaması 26,8 olup, katılımcılar ağırlıklı olarak ilkokul mezunu ve ev hanımıydı. ${ }^{16}$ Kısacık'ın çalışmasında, gebe kadınların yaş ortalaması 25,9 ve ortalama toplam gebelik sayis1 2,4 olup, mevcut gebeliklerin $\% 78,3^{\prime}$ ü istenerek oluşmuştu. ${ }^{17}$ Durualp, katılımcılarındaki mevcut gebeliği isteyerek planlama oranını \%81,5 olarak saptamıştır, aynı çalışmadaki gebeliklerin \%33,8'i ilk gebeliktir. ${ }^{18}$ Çalışmamızdaki yaş ortalaması 27,4'tür, katılımcılarımızın çoğu ortaöğretim mezunudur ve ağırlıklı olarak ilk 2 gebelik süreçlerindedir. Ayrıca, mevcut gebeliğin istemli olma oranı da, diğer çalışmalarla benzerlik göstermektedir.

Orta ve yüksek sosyoekonomik düzeye sahip kadınlarda, düşük sosyoekonomik düzeye sahip olanlara göre, sigara içme oranlarının daha yüksek düzeyde olduğu bilinmektedir. ${ }^{19}$ Türkiye Nüfus ve Sağlık Araştırması'nın sonuçlarına göre; kentsel alanlar ve İstanbul'da yaşayan kadınlarda sigara içme oranı daha yüksek olduğu, eğitim düzeyi arttıkça sigara içmenin de arttığı gösterilmiştir. ${ }^{9}$ Kendi verilerimize göre de, maddi durumu iyi olan gebelerde sigara içiciliğine daha sık rastlanıyordu. Çalışma bölgelerimizin kırsal ağırlıklı olması ise, düşük sigara içiciliği oranını açıklayabilir.

Literatüre göre, eşleri sigara içen gebelerin sigara içme oranı, eşi sigara içmeyenlerden anlamlı düzeyde yüksektir. Eşin sigara içmesi, gebenin sigaraya başlamasını kolaylaştırabilir, bırakmasını da zorlaştırabilir. $^{20}$ Marakoğlu ve Sezer, çalışma 
kapsamındaki kadınların eşlerinin sigara içme oranını \%68 olarak saptamıştır. ${ }^{11}$ Karaaltincaba'nın çalışmasında, gebelerin \% 69,2'sinin pasif içici olduğu belirlenmiștir. ${ }^{14}$ Nakumura ve arkadaşlarının yaptığı araştırmada, gebelikte pasif içicilik oranı \%35,9 olarak saptanmıştır. ${ }^{21}$ Bizim çalışmamızda, eş/yakınların \%48'i sigara içmekteydi, bu durum ile gebenin sigara içicisi olması arasında ilişki saptanmadı. Maddi durumu kötü olan gebelerin, eş/yakınlarında sigara içiciliğine daha sık rastland.

Sigaraya maruz kalan bebekte, erken membran rüptürüne, prematüre doğum ağrıları ve doğuma, plasental anomalilere, fetal toksisiteye, ani bebek ölüm sendromuna, down sendromu gelişimine, düşük doğum ağırlığına, hiperviskositeye, major doğumsal defektlere (yarık damak, vs), azalmış kemik dansitesine, çocukluk çağı hipertansiyonuna, büyümede gecikmeye, nörotoksisiteye, davranışsal psikiyatrik ve bilişsel yan etkilere, mental retardasyona, çocukluk kanserlerine, respiratuar hastalıklara daha sık rastlanmaktadır., ${ }^{722}$ Günde 1 paketin altında sigara içenlerde, düşük doğum ağırlıklı bebek doğurma riski \%50 artarken, 1 paketin üzerinde sigara içenlerde bu risk \%130 artış göstermektedir. Eğer anne 16. gebelik haftasından itibaren sigara içmeyi bırakırsa, bebekteki riskin hiç sigara içmeyenler ile neredeyse aynı olduğu görülmüştür. ${ }^{25}$

Marakoğlu ve Sezer'in çalışmasında, gebelerin \%95'i sigaranın "bebeğe çok zararlı" olduğunu düşünüyordu. ${ }^{11}$ Durualp'in çalışmasına katılan gebelerin ise, \%90'1 sigara içiminin zararlı olacağını, \%90,8'i sigara kullanımının bebekte gelişme geriliğine, \%73,9'u ölü doğumlara, \%75,4'ü erken doğumlara neden olacağını, \%82,3'ü düşük riskini, \%63,9'u yüksek tansiyon riskini arttırabileceğini, \%73,1'i bebekte zeka geriliğine, \%89,2'si akciğer hastalıklarına, \%55,4'ü plasenta ile ilgili bozukluklara neden olacağını düşünüyordu. ${ }^{18}$ Kendi gebelerimizde, sigaranın yol açacağı problemlerden, bilinirlik oranı en yüksek olanı ölü/ erken doğum idi (\%59). Bunun dışında hemen, hemen bütün patolojilerin bilinirliği \%50'nin altındaydı. İsteyerek gebe kalanlarda, bilgili olma düzeyi çok daha yüksekti. Eğitim düzeyi arttıkça, gelişebilecek problemler konusunda bilgili olma düzeyi artmaktaydı, fakat sigara içicisi olma oranı değişmemekteydi. Nijerya ve Pakistan gibi düşük eğitim düzeyli bölgelerde yapılan çalışmalarda, bebeğin yaşayabileceği problemlerin bilinme yüzdesi daha düşük, sigara içiciliği daha yüksekti. ${ }^{26}$ Grange ve ark., gebelerin sigara içiciliğinde birinci trimesterde azalma, üçüncü trimesterde ise artma gözlemlemiş, doğum sonrası ilk 6 ayda, sigara içmeye tekrar başlama eğiliminde olduklarını saptamıştır. ${ }^{26}$ Birinci trimesterdeki gebelerimizde, sigaranın zararları konusundaki bilgi düzeyi ilerleyen dönemlere göre daha yüksekti.
Özellikle, birinci trimesterde gebeler bilgiye ulaşma konusunda daha istekli, sağlık problemleri konusunda daha kaygılı olmaktadır.

\section{SONUÇ}

Bu çalışmada, katılımcılarımızın sigara içiciliğinin çok düşük düzeyde olduğu, fakat sigaranın bebek üzerindeki olumsuz etkileri konusunda yeterli bilgi düzeyine sahip olmadıkları görüldü. Özellikle, ASM'lerde görev yapan sağlı personelinin gebeleri sigara kullanımının sonuçları konusunda bilgilendirmeleri gerekmektedir. Sigara paketlerinin üzerinde gebe ve bebek ölümleri, sağlık problemleri ile ilgili görseller konulmalıdır. Gebeler, sigarayı bırakmaya teşvik edilmeli, gerekli durumlarda farmakoterapi denenmelidir.

\section{KAYNAKLAR}

1. Altıparmak S, Altıparmak O, Demirci Avcı H. Manisa'da gebelikte sigara kullanımı; yarı kentsel alan örneği. Tur Toraks Der 2009;10:20-5.

2. Turkey Statistical Institute, 2012. Global adult tobacco survey. http://www.tuik.gov.tr/PreHaberBultenleri.do?i $\mathrm{d}=13142$. Erişim: 15.11. 2017.

3. Doğu S, Ergin A. Gebe kadınların sigara kullanımını etkileyen faktörler ve gebelikteki zararlarına ilişkin bilgileri. Maltepe Üniversitesi Hemşirelik Bilim ve Sanatı Dergisi 2008;1(1):26-38.

4. Martin JA, et al. Births: final data for 2002, National Vital Statistics Reports, 2003; 52.

5. U.S. Department of Health and Human Services. The Health Consequences of Smoking: Nicotine Addiction. A Report of the Surgeon General. Atlanta (GA): U.S. Department of Health and Human Services, Public Health Service, Centers for Disease Control, National Center for Chronic Disease Prevention and Health Promotion, Office on Smoking and Health, 1988. DHHS Publication No. (CDC) 88-8406.

6. Kesim MD. Sigara ve gebelik. ŞEH tıp bülteni 2004, 38(2), 7-14.

7. Çınar N, Topal S, Altınkaynak S. Gebelikte sigara kullanımı ve pasif içiciliğin fetüs ve yenidoğan sağlığı üzerine etkileri. J hum rhythm - June 2015;1(2):52-57.

8. David J, Nea B, Robledo C, Saffer E, Beebe L, Wild R. Intrauterine tobacco exposure may alter auditory brainstem responses in newborns. Acta Obstetricia et Gynecologica. 2010; 89: 592-596.

9. Türkiye Nüfus ve Sağlık Araştırması 2008, sayfa 58. Ankara: Hacettepe Üniversitesi Hastaneleri Basımevi Yayın No: NEE.HÜ.09.01;2009. 
10. Tarhan P, Yilmaz T. Gebelikte Sigara Kullanımı ve Etkileyen Faktörler. HSP 2016;3(3):140-147.

11. Marakoğlu K, Sezer RE. Sivas'ta gebelikte sigara kullanımı. Cumhuriyet Üniversitesi Tip Fakültesi Dergisi 2003;25:157-64.

12. Ananth CV, Savitz DA, Luther ER. Maternal cigarette smoking as a risk factor for placental abruption, placenta previa, and uterine bleeding in pregnancy. Am $\mathrm{J}$ Epidemiol 1996;1:144:881-9.

13. Gomez C, Berlin I, Marquis P, et al. Expired air carbon monoxide concentration in mothers and their spouses above $5 \mathrm{ppm}$ is associated with decreased fetal growth. Preventive Medicine 2004;40:10-5.

14. Karcaaltincaba D, Kandemir Ö, Yalvac S, Güvendağ Güven ES, Yildirim BA, Haberal A. Cigarette smoking and pregnancy: results of a survey at a Turkish women's hospital in 1,020 patients. J Obstet Gynaecol 2009; 29(6): 480486.

15. Marakoğlu K, Erdem D. Konya'da gebe kadınların sigara içme konusundaki tutum ve davranışları. Erciyes Medical Journal 2007;29(1):047-055

16. Mutlu LC, Varol Saraçoğlu G. Prevalence of smoking and factors affecting smoking behaviour during pregnancy: A sample from Tekirdağ. Turk J Public Health 2014;12(1), 112.

17. Kısacık G, Gölbaşı Z. Gebe kadınların sigara içme davranışları ve gebelikte sigaranın etkilerine yönelik bilgileri. Turkiye Klinikleri J Gynecol Obst 2009;19(4):197-205.

18. Durualp E, Bektaș G, Ergin D, Karaca E, Topçu E. Annelerin sigara kullanımı ile yenidoğanın doğum kilosu, boyu ve baș çevresi arasındaki ilișkinin incelenmesi. Ankara Üniversitesi Tıp Fakültesi Mecmuası 2011, 64 (3), 119-26.

19. Caleyachetty R, Tait CA, Kengne AP, Corvalan C, Uauy R, o-Tcheugui JBE. Tobacco use in pregnant women: analysis of data from demographic and health surveys from 54 low-income and middle-income countries. Lancet Glob Health 2014; 2: 513520.

20. Nides MA, Rakos RF, Gonzales D, Murray RP, Tashkin DP, Bjornson-Benson WM, Lindgren $\mathrm{P}$, Connett JE. Predictors of initial smoking cessation and relapse through the first 2 years of the Lung Health Study. J Consult Clin Psychol 1995 Feb;63(1):60-9.

21. Nakamura MU, Alexandre SM, Kuhn dos Santos JF, de Souza E, Sass N, Auritscher Beck AP, Trayna E, Andrade CM, Barroso T, Kulay Júnior L. Obstetric and perinatal effects of active and/or passive smoking during pregnancy. Sao Paulo Med J 2004; 122(3):948.

22. Salması G, Grady R, Jones J, Mcdonald SD. Environmental tobacco smoke exposure and perinatal outcomes: a systematic review and meta-analyses. Acta Obstetricia et Gynecologica 2010; 89: 423-441.

23. Şahin M, Yurdakul M. Gebelik öncesi danışmanlık. İstanbul Üniversitesi Florance Nightingale Hemşirelik Dergisi 2012; 20(1): 80-85.

24. CC Obiora, CC Dim, BSC Uzochukwu, FO Ezugwu. Cigarette smoking and perception of its advertisement among antenatal clinic attendees in referral health facilities in Enugu, Nigeria. Niger J Clin Pract. 2015 JanFeb;18(1):80-5.

25. Seema Bhanji, Marie Andrades, Fawad Taj, Ali K Khuwaja. Factors related to knowledge and perception of women about smoking: a cross sectional study from a developing country. BMC Womens Health. 2011 May 24;11:16.

26. Grangé $G$, vays sière $C$, Borg ne $A$, Ouazana A, L'Huillier JP, valensi $P$, et al. Characteristics of tobacco with drawal in pregnant women. Eur J Obstet Gynecol Reprod Biol 2006; 125(1):38-43. 